2014

\title{
Heidegger and Our Twenty-first Century Experience of Ge-Stell
}

Theoore Kisiel

Northern Illinois University, tkisiel@niu.edu

Follow this and additional works at: https://fordham.bepress.com/phil_research

Part of the Continental Philosophy Commons, Digital Humanities Commons, and the Engineering Commons

\section{Recommended Citation}

Kisiel, Theoore, "Heidegger and Our Twenty-first Century Experience of Ge-Stell" (2014). Research Resources. 41.

https://fordham.bepress.com/phil_research/41

This Article is brought to you for free and open access by the Hermeneutic and Phenomenological Philosophies of Science at DigitalResearch@Fordham. It has been accepted for inclusion in Research Resources by an authorized administrator of DigitalResearch@Fordham.

For more information, please contact considine@fordham.edu. 


\title{
Heidegger and Our Twenty-first Century Experience of Ge-Stell
}

\author{
Theodore Kisiel
}

\begin{abstract}
I propose an etymological translation of Ge-Stell, Heidegger's word for the essence of modern technology, from its Greek and Latin roots as "syn-thetic com-posit[ion]ing," which presciently portends our twenty-first century experience of the internetted WorldWideWeb with its virtual infinity of websites in cyberspace, Global Positioning Systems, interlocking air traffic control grids, world-embracing weather maps, the 24-7 world news coverage of cable TV-networks like CNN, etc., etc.-all of which are structured by the complex programming based on the computerized and ultimately simple Leibnizian binary-digital logic generating an infinite number of combinations of the posit (1) and non-posit (0). The sharp contrast between the global time-space technologically foreshortened into instantaneity and simultaneity and the radically local time-space of our situated historical existence-in short, the temporal-spatial tension between Ge-Stell and Da-Seinis examined for ways and means of bringing them together in contemporaneous compatibility.
\end{abstract}

Martin Heidegger got as far as the atomic-space-cybernetic age in his meditations on technicity and modern technology. We ourselves have been able to experience the marvels of the twenty-first century advance into the internet revolution and its instantaneous global reaches, such that, for example, we and the entire world with us were virtual witnesses of the recent events that transpired in Abbotabad, Pakistan, almost immediately after they happened. ${ }^{1}$ We twenty-first century citizens of the world take for granted the convenience of stratospheric transportation networks and

\footnotetext{
${ }^{1}$ This talk, delivered on May 25, 2011 to the Heidegger Forschungsgruppe meeting in Messkirch, Germany, took as its example of virtually instantaneous global communication the raid on the compound of Osama bin Laden that took place in the early hours of May 2 East Asian time.
}

T. Kisiel $(\square)$

Northern Illinois University, 27W761 Washington Av,

Winfield, IL 60190, USA

e-mail: tkisiel@wpo.cso.niu.edu 
the satellitic transmission of instantaneous media events that enwrap the "global village" at every hour of every day by CNN. But modern technology had advanced sufficiently in Heidegger's day for him to be struck by the same drastic foreshortening of time and space and its global reach brought on by the radio technology of his time. Accordingly, what he had to say to us about the essence of modern technology in the twentieth century appears to apply as well, with some minor adjustments in terminology, to the more enhanced and advanced technological realities of the twenty-first century.

Such adjustments can easily be made in the single hyphenated word by which he defines the essence of modern technology, almost as ingenious as the single hyphenated word that defines his entire way of thought, namely, Da-Sein. For modern technicity, his one word is of course Ge-Stell. In the last three decades of his life, Heidegger repeatedly tells us what Ge-Stell is, and repeatedly notes that it is to be sharply distinguished from the ordinary everyday senses of Gestell, as in Büchergestell (bookcase) and Brillengestell (frame for eyeglasses). It must therefore be emphatically stated that Ge-Stell is simply NOT "frame, framework or enframing," the current English translations drawn directly from GermanEnglish dictionaries. What then is Ge-Stell in its global essentiality? It is, in Heidegger's breakdown of this single word, "die versammelnde Einheit aller Weisen des Stellens/the collective unity of all modes of setting in place, positioning, positing." "Im Ge-spricht die Versammlung, Vereinigung, das Zusammenbringen aller Weisen des Stellens/The prefix Ge- speaks to the gathering, unification, bringing-together of all kinds of placing and positioning." "Das Ge-Stell ist die Versammlung, die Gesamtheit aller Weisen des Stellens, die sich dem Menschenwesen in dem Maße auferlegen, in dem es gegenwärtig ek-sistiertl Ge-Stell is the gathering, the integration of all the modes of placing, positioning, and positing that impose themselves upon the human being in the manner in which the human being presently ex-sists."

Against the current English favorite of "enframing," I therefore propose an etymological translation of Ge-Stell from its Greek and Latin roots as "syn-thetic com-posit[ion]ing," where the Greek-rooted adjective 'synthetic' adds the note of artifactuality and even artificiality to the system of positions and posits. For me, Ge-Stell as "syn-thetic com-posit[ion]ing" presciently portends the twenty-first century globalizations of the internetted WorldWideWeb with its virtual infinity of websites in cyberspace, Global Positioning Systems (GPS), interlocking air traffic control grids, world-embracing weather maps, the 24-7 world news coverage of cable TV-networks like CNN, etc., etc., all of which are structured by the complex programming based on the computerized and ultimately simple Leibnizian

\footnotetext{
${ }^{2}$ Heidegger (1977b), 104. The citation is taken from the seminar at Le Thor in 1969.

${ }^{3}$ Ibid., 129. Citation taken from the seminar at Zähringen, 1973.

${ }^{4}$ Ibid., 126, Zähringen, 1973. The same point was already made in a rich note circa 1955, whose first sentence reads: "Im Wort 'Gestell' spricht die Versammlung des Stellens, in der 'Versammlung' spricht das Echo zum Logos, im 'Stellen' spricht das Echo der Thesis (Poiesis).” Heidegger (2009), 320; see also 327 and 365. Hereafter cited as GA76.
} 
binary-digital logic generating an infinite number of combinations of the posit (1) and non-posit (0). The synthetic compositing of computer logic thus maps out the grand artifact of the technological infrastructure that networks the entire globe of our planet Earth.

The phenomenon of technological globalization was already apparent by the time of the so-called "Great War" of 1914-1918, which was accordingly renamed the World War. One of the heroes of this highly mechanized war, Ernst Jünger, in his accounts of "totale Mobilmachung," the total mobilization that occurred in the last year of the war, began to attribute this phenomenon to planetarisches Technik and its use in the struggle for planetarische Herrschaft. This becomes Heidegger's word for globalization in this period to phenomenologically describe the human experience that results from the network of grids constructed by modern technology to guide and control the so-called "air waves" which harness the natural electromagnetic radiation occurring across the surface of our planet Earth for human use and consumption. Globalization is essentially a time-space term, a dynamic term that spells out a quasi-infinite velocity in nanoseconds through its virtual abolition of space into bi-locative simultaneity and its instantaneous reduction of all time differences. By the early twentieth century, radio technology had advanced sufficiently for Heidegger to be struck by the drastic foreshortening of time and space and its global reach. In the famous 'pincers' passage of SS 1935, Heidegger dramatically describes the global geopolitical as well as philosophical situation of a postwar Germany being squeezed by two international movements, both of them technological juggernauts, on the western front by American capitalism and on the eastern front by Bolshevistic communism, in the following words:

Russia and America, when viewed metaphysically, are both the same: the same hopeless
frenzy of unchained technology and of the groundless organization of the average man.
When the farthest corner of the globe [der Erdball, the terrestial globe versus Heidegger's
beloved terra firma] has been technically conquered and can be economically exploited;
when any incident you like, in any place you like, at any time you like, becomes acces-
sible as fast as you like; when you [by way of radio] can simultaneously "experience" an
assassination attempt against a [Yugoslavian] king in France and a symphony concert in
Tokyo; when time is nothing but speed, instantaneity, and simultaneity, and time as his-
tory has vanished from the Dasein of all peoples; when a boxer counts as the great man
of a people; when the tallies of millions at mass meetings are a triumph; then, yes then,
there still looms like a specter over all this uproar the question: what for?- where to?-
and what then? [...in short, the question of be-ing in the twentieth century...] $]^{5}$

Clearly, Heidegger was suspicious of this instantaneity and simultaneity of the time technologized by global communication primarily because it abolishes the time of situated history, the time of Da-sein. In 1935, this time-space abolition results from the medium of the radio along with the wire services of newspapers, but it just as readily reflects with uncanny foresight the more advanced digitalmedia systems of the twenty-first century. As Heidegger observes in 1949, by plane

\footnotetext{
${ }^{5}$ Heidegger (1953), 28f. English translation by Gregory Fried and Richard Polt (2000a), 40. Emphasis added.
} 
and by radio and soon by TV, "all distances in time and space are shrinking." $\mathrm{He}$ calls this the phenomenon of the distanceless [das Abstandslose]. Distant locales and exotic places are shown on TV or film so realistically that you may even feel that YOU ARE THERE [as we were, most recently, in Abbottabad, Pakistan] there and there and everywhere in a technologically induced bi-locative simultaneity. Heidegger asks: "What is happening here when, as a result of the abolition of great distances, everything is equally far and equally near? What is this uniformity in which everything is neither far nor near, is, as it were, without distance? Everything gets lumped together into uniform distancelessness [Abstandslosigkeit]. How? Is not this merging of all into the distanceless more unearthly than everything blowing up [by way of the atomic bomb]?"” What Heidegger misses in this all-too-familiar modern experience is a genuine experience of nearness, the proximity of be-ing. Because the experience of nearness fails to materialize with this abolition of all distances, the phenomenon of the distanceless has come to dominate our lives in the twenty-first century. ${ }^{8}$

Heidegger's own examples of Ge-Stell begin in a farmer's field about to be exploited for its mineral deposits, be it for coal or uranium ore. Instead of being cultivated, the land is now being challenged [sich gestellt] to yield energy, where we set upon ${ }^{9}$ the land in order to extract coal or ore from it, then store this energy resource in order to have it ready for use. The hydroelectric plant is set into the river Rhine, thereby damming it up to build up water pressure which then sets the turbines turning whose thrust in turn generates and sets the electric current going into the network of long-distance cables, where the systematic transforming, storing, distributing and switching of electrical energy takes place. ${ }^{10} \mathrm{Be}$ it coal or hydroelectric power or atomic energy, in each case "Nature is positioned for its energy," nature is forced to yield its energy. Nature, thus held up to yield energy, emerges henceforth as the "storage-place of energy," like a global fuel depot or gigantic gas station.

Storage of resources, be it energy or information, becomes a central feature of the Ge-Stell, which Heidegger calls its fundamental unconcealment. "Everywhere, everything is ordered to stand by [es wird bestellt, auf der Stelle zu stehen], to be immediately in position for use, in fact to stand there to be on call for a further ordering [Bestellen]. [...] Whatever is ordered about in this way has its own standing. We call it the standing-reserve [Bestand]." And now comes the perhaps surprising denouement of Ge-Stell from the philosophical perspective: "Whatever stands

\footnotetext{
${ }^{6}$ Heidegger (1994), 3, citing from the preface to the lecture, "Das Ding." English translation by Albert Hofstadter in Heidegger (1971b), 165.

${ }^{7}$ Ibid., 4/166.

${ }^{8}$ Ibid., 20/181.

${ }^{9}$ Here, stellen is translated in various idioms of "to set." The typical translations of stellen are "put, place, set, stand," with strong overlaps with the verbs setzen and legen.

${ }^{10}$ Heidegger (1954b), 23-24, citing from the 1953 version of "Die Frage nach der Technik." English translation by William Lovitt in (1977a), 16.
} 
by in the sense of standing-reserve no longer stands over against us as object."11 "Thus when man, in investigating and observing, ensnares nature as an area of his own conceiving, he has already been claimed by a way of revealing that challenges him to approach nature as an object of research, until even the object disappears into the objectlessness of standing-reserve." 12 Heidegger in a parallel essay also notes that the most recent cyclotron experiments in nuclear physics likewise encounter this phenomenon of the complete disappearance of the object, which hitherto had been the very hallmark of modern science. But "that does not mean that the subjectobject relation vanishes, but rather the opposite: it now attains its most extreme dominance, predetermined from out of Ge-Stell, syn-thetic com-positioning. It becomes a standing-reserve [Bestand] to be commanded and placed on order." 13 The subject-object relation now reaches, for the first time, its purely 'relational' character, that is, its character of orderability [Bestellungscharakter], in which both the subject and the object are claimed as standing-reserves [Bestände].

The more modern technology unfolds and develops, the more objectivity transforms itself into disposability (into a making-itself-available). Gegenständlichkeit is transformed into Beständlichkeit. Now there are no more objects (no more beings standing over against a subject that takes them into view) — there are only Bestände, to wit, reserve resources positioned for orderability: stock on hand, stored inventory, warehoused supplies and provisions, capital holdings, assets, funds held in reserve (in short, beings held ready for plan-directed use). Political economists in fact no longer deal with objects but instead systematically order the space with an overall plan toward maximizing the utility of resources. Beings as a whole are aligned and ordered within a horizon of usefulness, domination or, better still, the disposability [Beständlichkeit] of all that needs to be placed under control. The planners themselves are no longer scientifically oriented toward a field of objects but now emerge in their true gestalt as technicians and even technocrats, i.e., humans who see beings a priori in the horizon of making-them-useful. It can no longer appear in the objective neutrality of an over-against. There is nothing other than reserve resources: warehoused stock, inventories of goods, stores of supplies, stockpiles of uranium, reserves of provisions, energy reserves, capital reserves, federal reserve funds, ${ }^{14}$ not to speak of the quasi-infinite store of information in the so-called memory banks of the internetted WorldWideWeb. "The ontological definition of reserve stock is not the persistence of durable goods but their character of disposability, the constant possibility of being offered and ordered, i.e., of enduring availability. Its constancy is not that of objectness but that of the standing reserve, a constancy defined in terms of syn-thetic com-positioning. In disposability, the being is posited as being exclusively available from the ground up, available for use in the planning

\footnotetext{
${ }^{11}$ Ibid., 24/17.

${ }^{12}$ Ibid., 27/19.

${ }^{13}$ Ibid., 61/173, citing from the essay "Wissenschaft und Besinnung."

${ }^{14}$ Heidegger (1977b), 105-6.
} 
of the whole."15 There are no longer any objects but only 'production resources' and 'consumer goods' at the disposal of everyone, who themselves are put into service in the business of production and consumption. In universities (now called "knowledge industries") as well as in corporations, personnel departments are now called departments of human resources. And since all resources are disposable, they are at once replaceable. This is clearly manifest in the industry of consumer goods with its abundance of substitutes and, in an era of mass production, leads to the tendency to replace rather than repair used goods. ${ }^{16}$ But extending the same attitudes to human resources is fraught with all manners of abuse, the extremes of which we have witnessed under the totalitarian regimes of the twentieth century.

The recent disruption in the global flow of standing reserves caused by the Japanese earthquake illustrates another phenomenon unique to modern technicity, namely, that Heidegger's broken hammer experience has gone global. The widely adopted Toyota strategy of just-in-time inventories for its production lines led, as a result of the earthquake, to drastic disruptions in the supply lines of numerous automobile production lines around the world. Massive power outages and recent identity thefts of mega-lists pirated on the internet are further examples of the broken hammer experience gone global. Recall the fears of massive attacks on the Internet and WorldWideWeb by cyber-terrorists in the millennial year of Y2K. Among other things, it conjures the image of the lightning-speed electronic circulation of vast sums of currency whipping around the world's financial markets in a global cash flow whose reverberations sometimes verge on a cascading collapse. Such a globally impelled crash, whether by impersonal market forces or computer hackers, would make the worldwide depression of 1929, at least in its velocity of impact, pale in insignificance.

To be sure, all of these examples of global disruption occur in the high-velocity time-space of modern technicity, which is not at all comparable with the more vitally measured time-space of the broken hammer experience. Recall that the broken hammer experience retrospectively reminds us of the referential context and its vital connections that the broken hammer interrupts, say, in the work world of the carpenter. At one point, Heidegger asks what exactly is the "basic referential context" (GA76, 302: Grundverweisungszusammenhang) of a "world" of machination and notes its radical difference from the referential world of handwork and hand tools by pointing to the regulated and uninterrupted repeatability "in exactly the same way" of the "mechanical" motions of the machine and the more calculative referential relations necessary for its manufacture. ${ }^{17}$ The "machine is not an 'imitation' of handwork and natural processes but rather a self-standing organization of all the processes of beings." ${ }^{18}$ And this "organization of all the processes of beings" in its deliberately calculated mechanical design is not even a world.

\footnotetext{
${ }^{15}$ Ibid., 106.

${ }^{16}$ Ibid., 107.

${ }^{17} \mathrm{GA} 76,307$.

${ }^{18} \mathrm{GA} 76,308$.
} 
Heidegger thus speaks of an "unworlding and unearthing of beings" in the machinations of Ge-Stell, ${ }^{19}$ where beings stand in a state of total abandonment by be-ing [Seinsverlassenheit $].{ }^{20}$

We are accordingly moving from the epoch of objectivity [Gegenständlichkeit] to the epoch of disposability [Beständlichkeit], the most extreme gestalt of the history of the metaphysics of constant presence since the Greeks. "Because we no longer encounter what is called Ge-Stell within the horizon of representation, the view that allows us to think of the be-ing of beings as presence, Ge-Stell no longer approaches us as something present and thus seems at first alien and strange." ${ }^{21}$ As the most extreme gestalt of the history of the metaphysics of constant presence, and so the completion and fulfillment of this metaphysics, the Ge-Stell assumes a strange constant absence which in effect serves to point it in another direction, to serve as a passage from metaphysics to another thinking governed by the properizing event, das Er-eignis. The Ge-Stell is "Janus-faced, it is essentially double-sided [...] it is so to speak the photographic negative of the event, das Ereignis." 22 Accordingly, "an outstanding way to draw near to das Er-eignis, the properizing event, would be to look deeply into the essence of Ge-Stell." 23 The Ge-Stell thus prompts Be-sinnung, a meditation on its meaning. It is therefore not a matter of regarding the emergence of technology as a negative event (and certainly even less as a positive event, as if it were a paradise on earth). "That in and from which man and be-ing approach and challenge each other in the technological world claims us in the manner of Ge-Stell, syn-thetic com-positioning. In the reciprocal self-positing [Sichstellen] of man and be-ing we discern the claim that defines the constellation of our age." ${ }^{24}$ With the Ge-Stell, it appears that we are on the verge of overcoming the subject-object relation and entering into the mutual ownership of man and being that the properizing event is.

The intimate be-longing together of man and be-ing in the manner of a mutual escalating challenge brings us in startling fashion nearer to that and how man is delivered over to the ownership of be-ing and be-ing is appropriated to the essence of man. Within Ge-Stell there prevails a rare and exceptional ownership and appropriation. We must simply experience this owning in which man and be-ing are proper for one another, i.e., we must enter into what we call the event of enownment and properizing, das Ereignis ... a singulare tantum ... unique ... What we experience in Ge-Stell as the constellation of be-ing and man through the modern world of technology is a prelude to what is called Er-eignis. For in the event there resides the possibility that it may turn the sheer prevalence of Ge-Stell into a more inceptive appropriating. Such a transformation of Ge-Stell into das Er-eignis would by virtue of this event bring the appropriate recovery-appropriate, thus never to be made by

\footnotetext{
${ }^{19} \mathrm{GA} 76,307$.

${ }^{20} \mathrm{GA76}, 297$.

${ }^{21}$ Heidegger (1957), 28. English translation by Joan Stambaugh (1969), $35 f$.

${ }^{22}$ Heidegger (1977b), 104.

${ }^{23} \mathrm{Ibid}$.

${ }^{24}$ Heidegger (1957), 27f./35.
} 
man alone - of the world of technology out of its domination to servitude in the realm by which man reaches more properly into the properizing event. ${ }^{25}$

Presuming that we could wait in anticipation for the possibility that Ge-Stell, the reciprocal challenge of man and be-ing in the calculation of the calculable, would address itself to us as the appropriating event that first expropriates man and be-ing into their proper [character]; then a path would be freed for man to experience beings in a more inceptive way - the totality of the modern technological world, nature, and history, and above all their be-ing. ${ }^{26}$

In Heidegger's depiction, therefore, at the most extreme extremity of the history of the metaphysics of constant presence, we find ourselves poised at the very threshold of crossing over into an authentic experience of be-ing in the propriating event, das Er-eignis. But despite the apparent and so tantalizing proximity of this ex-perience, we are not given to expect a smooth gradual crossing over to it simply because of the extremities at which we are poised: the machinations of technology have resulted in the complete abandonment of beings by be-ing [Seinsverlassenheit] and the human being is in peril of not only forgetting his essential be-ing but even of having forgotten this forgetting of be-ing. "But in this extreme extremity of destining peril the most intimate relationship [of man and be-ing] shows itself, but shows itself only as a completely veiled hint." ${ }^{27}$ It is necessary to push the ex-perience of the peril of technology to the extreme to glimpse the e-vent emerging in the $\mathrm{Ge}$-Stell. Accordingly, Heidegger recommends not attempting to arrest or to master technology but to drive it to its extreme in order to ex-peri-ence it in its full peril to the human being, and at the same time to meditate on the meaning of its destining essence. ${ }^{28}$ To put this extreme experience in another way, technology in its essence is the "most extreme neglect [Ver-wahr-losung] of the under-cut of difference [Unter-schied, of be-ing and beings].... Technology - the neglect of (nearness), yet accordingly in this neglect [we find] the nearing of the turn of the forgottenness of the under-cut of difference." 29 Finally, Heidegger, following Hölderlin, prompts the "sons of the Alps" to make the perilous crossing "over the abyss on lightly built bridges" by invoking these encouraging lines from Hölderlin's Patmos: "Wo aber Gefahr ist, wächst/Das Rettende auch//But where peril is also grows the saving." How the extreme peril of technology might allow us to glimpse "the growing light of a saving [power]" is suggested by the hint that the Greek word techne is the common root of both technology and art, even the fine arts. ${ }^{30}$ By way of this hint, Ge-Stell at its extreme of unworlding [Entweltung] and unearthing [Enterdung] may well be transformable into the world and earth of das Geviert.

This crossing over from Ge-Stell to Geviert once again operates between extremes that, in their very contrast, provide clues for the crossing. How? Consider,

\footnotetext{
${ }^{25}$ Heidegger (1957), 28f./36f.

${ }^{26}$ Ibid., 32f./40.

${ }^{27} \mathrm{GA} 76,327$.

${ }^{28} \mathrm{GA} 76,255$.

${ }^{29} \mathrm{GA} 76,370$.

${ }^{30}$ Heidegger (1954b)/(1977a), 36-43/28-35.
} 
for example, the abolition of time and space that comes with modern technology, where everything is equally far and equally near, inducing a uniformity in which everything is neither far nor near, is, as it were, without distance, such that everything gets lumped together into a uniform distancelessness [Abstandslosigkeit]. What is missing in this all-too-familiar modern experience of time and space is a genuine experience of nearness, the proximity of be-ing. But that very experience of missing the near opposed to the far in their authentic presential sense is the beginning of meditative thinking - for which nearness can become conspicuous by its very absence-and of the turn toward moving beyond the essence of modern technology as Ge-Stell, which in its essence does not admit of any qualitative nearness or farness. ${ }^{31} \mathrm{Ge}$-Stell in its essence disallows nearness. And what nearness [Nähe] truly nears is the intimacy of a world as a neighborhood [Nähe] in which we can dwell meaningfully. "Ge-Stell as the completed destining of the forgottenness of the essence of be-ing inconspicuously radiates a ray of the distant arrival of world. The fact that world withholds its worlding here does not mean that nothing happens with world: the withholding itself radiates the lofty nearness of the most distant farness of world." 33

A crucial opposition is clearly emerging in our consideration of modern technicity, namely, the contradistinction between the technical time-space of the distanceless versus the time-space of historical Dasein. In SS 1928 Heidegger characterized the historical world as a temporal playing field [Zeit-Spiel-Raum] that grants Da-sein the freedom of movement within a finite world of distinct historical possibilities. One is tempted nowadays to compare this basic contradistinction with that between the cyberspace of virtual reality and the concrete space of historical reality, by way of the many recent crossovers from virtual to historical reality in organizing protest movements on line, be it environmental, economic, and most recently, that of the "Arab spring." The most recent twenty-first century technologies like the internet have by and large had a liberating effect as compared to the twentieth century, which often employed technology as totalitarian tools of domination like the propaganda propagated by newspapers/radio/film and the leveling of das Man to uniformity and conformity. Have '1984' and 'Big Brother' become figments of the past now overcome, at least on the global scale in which they were fictionally portrayed?

On other occasions, Heidegger describes this contradistinction in terms of technical-functional relations versus vitally lived relations, or, a bit more deeply, as the contradistinction between a technical world of functionality and a lived world of meaningfulness, which are the topics of two radically different kinds of thinking, calculative thinking and meditative thinking [be-sinnendes Denken], which accordingly meditates on the meaning [Sinn] of be-ing. In the Spiegel Interview of 1966, for example, where Heidegger admits to being frightened [erschrocken] when he first saw the pictures of the earth taken from the moon, he remarks: "We do not

\footnotetext{
${ }^{31}$ Heidegger (1994), 45.

${ }^{32}$ Ibid., 46.

${ }^{33}$ Ibid., 53.
} 
need atomic bombs at all [to uproot us] - the uprooting of man is already here. All our relationships have become merely technical ones. It is no longer upon an earth that man lives today." ${ }^{34}$ He finds it uncanny to be living in a world in which everything is pure function, and this functioning simply leads to more and more functioning, and this technicity increasingly dislodges man and uproots him from the earth and native roots. This takes us to another formulation of our contradistinction, that of the global versus the local, which came into currency with the generation that lived through the PC (personal computer) revolution but is quite apt to the old Heidegger's concerns, as he meditates on the impact of technological giganticism on local traditions and on the rhythms and ways of life of the "good old days."

\section{Autochthony in the Atomic Age}

Heidegger assumes a less terrified and more meditative and placid [gelassene] tone toward Ge-Stell in his 1955 talk in Messkirch memorializing the hometown composer Conradin Kreuzer, published under the title Gelassenheit but whose original title for the hometown crowd that first heard it was "Bodenständigkeit im Atomzeitalter," "Autochthony in the Atomic Age." ${ }^{35}$ He notes here that it is not only schwäbischer Boden-der Geniewinkel - that has produced great poets and thinkers, but also the Boden of Middle Germany, East Prussia, Silesia as well as Bohemia has inspired its great poets and thinkers. ${ }^{36}$ What is this ground that produces great poets and thinkers? Nothing less than the native language in which one finds oneself rooted, the earth of language in its dialects in their tonality, rhythms, and song, in short, the down-to-earth language of original experience. ${ }^{37}$

To come to terms with the inexorable onslaught of modern technology on his hometown and environs, Heidegger recommends that his Landsmenschen should

\footnotetext{
${ }^{34}$ Heidegger (2000b), 669-670; translated by William Richardson as “'Only a God Can Save Us': The Spiegel Interview (1966)," Heidegger (1981), 56.

${ }^{35}$ The adjective bodenständig is typically translated as "indigenous, native" so that the more abstract Bodenständigkeit etymologically suggests being native to a land or a nation and, even more starkly (and mythologically), having one's roots in native soil. Whence the clear possibility of using this term for nationalistic and even for racist ends, as was the case in Nazi Blubo (=Blut und Boden) propaganda. And Heidegger here is speaking directly to a post-war native German audience. But it should be noted that Heidegger first used the word often enough in the twenties in a phenomenological and so non-nationalistic context to connote the re-duction "back to the origins, roots, native ground" of original experience. This is important to note when we try to redirect his suggestions toward our own unique situation of being caught up in our twenty-first century Ge-Stell.

${ }^{36}$ Heidegger (1959), 16; translated by John M. Anderson and E. Hans Freund as Discourse on Thinking Heidegger (1966), 47.

${ }^{37}$ It might be noted here that Colonel Claus von Stauffenberg, who was born and raised not too far from Messkirch, also developed his poetic sense of the Germany for which he was willing to fight and die directly from schwäbischem Boden, inspired especially by the poetry of Hölderlin and Stefan George.
} 
strive to cultivate two basic comportments to meditatively confront the flood of technical devices that were already working their way into the life and fabric of the town and gradually making themselves more or less indispensable. The first comportment involves affirming the unavoidable use of technical devices but denying them the right to dominate our lives, i.e., of letting technical things be what they are but then of willing to let them go to avoid becoming slavishly dependent on them. Heidegger identifies this yes-no comportment toward technical devices as the releasement toward things [Gelassenheit zu den Dingen]. "Having this comportment we no longer view things merely in a technical way. ... We notice that while the production and use of machines demands of us another relation to things, it is not a meaning-less [sinn-los] relation. Farming and agriculture, e.g., have now become a motorized food industry. Thus here, evidently, as elsewhere, a profound change is taking place in man's relation to nature and to the world. But the meaning [Sinn] that reigns in this change remains obscure." 38 The issue here, accordingly, is to make sense of all this high tech infiltrating into our lives by way of meditative [be-sinnendes] thinking. For example, what are we to make of the fact that "Nature is becoming a gigantic gas station, an energy source for modern technology and industry," 39 a storage-place for energy, thus a "natural resource" subject to the calculations of those wishing to exploit it for profit or conquest?

\begin{abstract}
There is then in all technical processes a meaning, not invented or made by us, which lays claim to what we do and leave undone. We do not know the significance of the uncanny increasing dominance of atomic technology. The meaning pervading technology hides itself. But if we explicitly and continuously heed the fact that such hidden meaning touches us everywhere in the world of technology we stand at once within the realm of that which hides itself from us, and hides itself just in approaching us. That which shows itself and at the same time withdraws is the essential trait of what we call the mystery. I call the comportment that enables us to remain open to the meaning hidden in technology, openness for the mystery [Offenheit für das Geheimnis]. ${ }^{40}$
\end{abstract}

Releasement to and from technical things and openness for the mystery of the meaning of modern technicity: These two comportments combined serve to promote meditative thinking and so to counter the threat of becoming so bedazzled by the marvels of modern technology that calculative thinking comes to be accepted as the only way of thinking. Humans would thereby deny and throw away their essential nature of being meditative beings and no longer nurture their capacity for meditative thinking. ${ }^{41}$ In our present situation, we are called upon to be open to the mystery of the global domination of technology and to meditatively ponder the profound changes that it is exacting upon our relations with nature and the world in order that we might find meaningful ways for us to live in this new world. For these two comportments "grant us the possibility of dwelling in the world in a totally different way. They promise us a new ground and foundation [Boden] upon

\footnotetext{
${ }^{38}$ Heidegger (1959), 25; (1966), 54f.

${ }^{39}$ Ibid., 20/50.

${ }^{40}$ Ibid., $25 \mathrm{f} / 55$.

${ }^{41}$ Ibid., $27 / 56$.
} 
which we can stand and endure in the world of technology without being imperiled by it. ... They give us a vision of a new autochthony [Bodenständigkeit] that someday might even be fit to bring back the old and now rapidly disappearing autochthony in a transformed gestalt." 42 "If releasement toward things and openness toward the mystery awaken within us, we might arrive at a path that will lead to a new ground and foundation [Boden]. In that Boden the creativity that produces lasting works could strike new roots." ${ }^{43}$

What would such "lasting works" created out of the new autochthony look like? Would they involve some sort of fusion of technology and art, some sort of "tech art," as suggested by the Greek techne, which means both art and technology? At one point, Heidegger does hint broadly that an autobahn bridge might be a candidate for gathering the fourfold. ${ }^{44}$ But can a Boeing-787 taking off ever gather the fourfold? We know that Heidegger developed an appreciation for Paul Klee and modern art later on in life. Or would it involve an Eastern approach to art, like the Taoism that comes into play in the jug that jugs? Then there is the feng shui approach to architecture, which Heidegger spontaneously applied in his account of how a Schwarzwald Bauernhof gathers the fourfold. ${ }^{45}$ Since the resolution to modern technicity is bound to pass to some extent through art, it is worth concluding by examining Heidegger's sense of the artwork for clues to the possible transition from Ge-Stell to das Er-eignis.

\section{How the Artwork Works in a Historically Local Context}

Heidegger's early use of the hyphenated word Ge-stell in 1935 as it operates in the gestalt of an artwork evokes a 1956 cautionary note from him to distance this more focused "local" sense from the modern meaning of Ge-Stell operative on a global scale in modern technicity. But it also opens the opportunity for us to examine the different sort of gathering of modes of stellen, the different kinds of settings and positioning that are operative in an artwork.

First of all, "To be a work means to set up [aufstellen] a world." ${ }^{46}$ In setting up the world, the work sets forth [her-stellt] the earth, accordingly with herstellen being taken in the strict etymological sense of the word. The work sets itself back [sich zurïckstellt] and thereby puts the earth into the openness of a world.

\footnotetext{
${ }^{42}$ Ibid., 26/55.

${ }^{43}$ Ibid., 28/56f.

${ }^{44}$ Heidegger (1954a), 153; translated by Alfred Hofstadter as "Building Dwelling Thinking" in Heidegger (1971b), 152.

${ }^{45}$ Ibid., 161/160.

${ }^{46}$ Heidegger (1950), 33; translated by Alfred Hofstadter as "The Origin of the Work of Art" in Heidegger (1971b), 44.
} 
That into which the work sets itself back [zurückstellt] and which it lets come forth in this setting back of itself we called the earth. ... In setting up a world, the work sets forth the earth. ... To set forth the earth means to bring it into the open as the self-closing. ${ }^{47}$

"The setting up of a world and the setting forth of earth are two essential traits of the work-being of the work. They belong together in the unity of work-being." 48

The world is the self-opening openness of the broad courses of the simple and essential decisions in the destiny of a historical people. The earth is the spontaneous coming forth of the continually self-closing and accordingly covering and sheltering. World and earth are essentially different from one another and yet are never separated. The world grounds itself upon the earth and the earth towers through the world. ${ }^{49}$

"The opposition of world and earth is a strife." 50 "Inasmuch as the work sets up a world and sets forth the earth, it is an institution of this strife." "The work-being of the work consists in the strifing of the strife between world and earth." 51 The strife here is between the self-opening openness of the world and the self-closing closedness and so covering sheltering of the earth, in short, the strife between unconcealing and concealing, the happening of truth. "Truth happens only by establishing itself in [both] the strife and the playing space [Spielraum] that it itself opens up." "Truth establishes itself in the work. Truth comes to presence [west] only as the strife of clearing and concealing in the opposition between world and earth." 53

One final setting [Stellen] must be made for the work to do its work as a happening of truth. Having set itself up [aufstellt] as world and set itself forth (her-stellt) as earth by setting itself back [zurückstellen] into the earth, the work must now set and fix in place [feststellen] the strife of truth in the gestalt. Put another way, the truth must establish itself by being fixed in place in the gestalt of an artwork. "Art is the setting and fixing in place of self-establishing truth in the gestalt." 54 The Greek sense of morphe as gestalt or form is made clear by Ge-stell, understood as the gathering together of the various settings of truth in the rift-design of the bounding outline (peras) of the gestalt.

In the creating of the work, the strife as rift must be set back [zurückgestellt] into the earth, and the earth itself must be set forth [hervorgestellt] and used as the selfclosing. Such use, however, does not use up or misuse the earth as matter, mere stuff, but rather frees the earth to be just itself. This use of the earth is a working with it that indeed looks like the employment of matter in handicraft. Hence the appearance that artistic creation is also craft activity. It simply is NOT. But it is

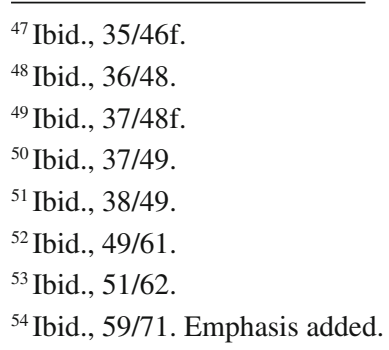


always a use of the earth in the setting and fixing in place of truth in the gestalt. In contrast, the making of tools and equipment is never immediately the effecting of the happening of truth. The production of equipment is finished when a material has been sufficiently formed to have it ready for use. The equipment's readiness for use means that it is released beyond itself to disappear into usefulness. ${ }^{55}$

In the artwork, by contrast, its matter is not used up and does not disappear but is rather set forth as earth into the openness of the world. Rather than using up words in the manner of everyday discourse, the poet uses the word "such that the word truly becomes a word and remains a word" in all its glory and brilliance. This is the Bodenständigkeit or earth-rootedness of language so cherished by Heidegger.

"The poetizing project of truth, which sets itself (sich stellt) into the work as a gestalt, is never enacted in an indeterminate void. Rather, the truth in the work is projected to the coming preservers, i.e. to a historical humanity [and not a Volk!]."56 The preservers in their Dasein now take their place in the in-between and in the middle of the strife of world and earth, unconcealment and concealment. With the artwork we are in a historical world of a historical people in search of its destiny, not in the uniform technological time-space of the distanceless, but rather in the time-space of historical Dasein. It is the temporal playing field [Zeit-Spiel-Raum] of history that grants us freedom of movement in and through a historical world of distinct finite possibilities. And the artwork itself is just one of the forms of the historical happening of truth, along with philosophical questioning, state-founding deeds, and essential sacrifice, like the "people-saving death" of Albert Leo Schlageter. "The world is the self-opening openness of the broad courses of the simple and essential decisions in the destiny of a historical people." ${ }^{57}$ Such a historical world with its tradition of deeds and sacrifices and concepts offers a people an appointed task [Aufgegebenes] which points them to their future world of possibilities. This appointed task unique to a people at once discloses to them a native endowment [Mitgegebenes] already given to them on the basis of what they have been. Clearly, the appointed task of today's historical humanity is to ponder the profound change that is taking place by way of the essence of modern technology, Ge-Stell, and to ready itself to cope with these changes in a way that remains true to our own unique proper situation of be-ing, in which "das Leben selbst legt sich aus," life itself lays itself out, interprets itself, explicates itself. This domain of original meaningfulness which precedes the subject-object relation is what must be repeatedly retrieved and retained so that we may once again learn to live poetically on the earth in a post-modern world of technology.

\footnotetext{
${ }^{55}$ Ibid., 52/64. Emphasis added.

${ }^{56}$ Ibid., 63/75.

${ }^{57}$ Ibid., 37/49.
} 


\section{References}

Heidegger, Martin. 1950. Der Ursprung des Kunstwerkes. In Holzwege, ed. Martin Heidegger. Frankfurt am Main: Klostermann.

Heidegger, Martin. 1953. Einführung in die Metaphysik. Tübingen: Max Niemeyer.

Heidegger, Martin. 1954a. Bauen Wohnen Denken. In Vorträge und Aufsätze. Pfullingen: Neske.

Heidegger, Martin. 1954b. Vorträge und Aufsätze. Pfullingen: Neske.

Heidegger, Martin. 1957. Identität und Differenz. Pfullingen: Neske.

Heidegger, Martin. 1959. Gelassenheit. Pfullingen: Neske.

Heidegger, Martin. 1966. Discourse on Thinking. Trans. John M. Anderson and E. Hans Freund. New York: Harper \& Row.

Heidegger, Martin. 1969. Identity and Difference. Trans. Joan Stambaugh. New York: Harper \& Row.

Heidegger, Martin. 1971a. Building dwelling thinking. In Poetry, Language, Thought, ed. Heidegger. Trans. Alfred Hofstadter. San Francisco: Harper \& Row.

Heidegger, Martin. 1971b. Poetry, Language, Thought. Trans. Albert Hofstadter. San Francisco: Harper \& Row.

Heidegger, Martin. 1971c. The origin of the work of art. In Poetry, Language, Thought, ed. Heidegger. Trans. Alfred Hofstadter. San Francisco: Harper \& Row.

Heidegger, Martin. 1977a. The Question Concerning Technology and Other Essays. Trans. William Lovitt. San Francisco: Harper \& Row.

Heidegger, Martin. 1977b. Vier Seminare. Frankfurt am Main: Vittorio Klostermann.

Heidegger, Martin. 1981. 'Only a god can save us': The Spiegel interview (1966). In Heidegger: The Man and the Thinker, ed. Thomas Sheehan, 56f. Trans. William Richardson. Chicago: Precedent.

Heidegger, Martin. 1994. Das Ding; Das Ge-Stell; Die Gefahr. In Bremer und Freiburger Vorträge, Gesamtausgabe, vol. 79, ed. Jaeger Petra. Frankfurt am Main: Klostermann, pp. 5-21, 24-45, $46-67$.

Heidegger, Martin. 2000a. Introduction to Metaphysics. Trans. Gregory Fried and Richard Polt. New Haven: Yale University Press.

Heidegger, Martin. 2000b. Spiegel-Gespräch mit Martin Heidegger. In GA 16: Reden und andere Zeugnisse eines Lebensweges, 669-670. Frankfurt am Main: Klostermann.

Heidegger, Martin. 2009. Leitgedanken zur Entstehung der Metaphysik, der neuzeitlichen Wissenschaft und der modernen Technik, Gesamtausgabe, vol. 76, ed. Strube Claudius. Frankfurt am Main: Klostermann. 